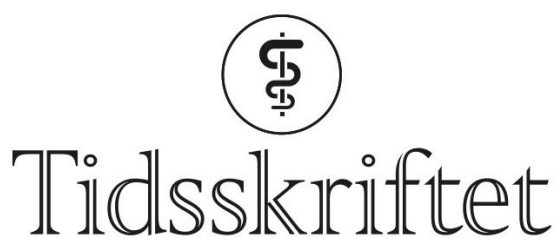

DEN NORSKE LEGEFORENING

\title{
Epigenetikk, etikk og militære utenlandsoppdrag
}

KOMMENTAR

\section{BAARD INGEGERDSSON FREBERG}

E-post: baard.freberg@gmail.com

Baard Ingegerdsson Freberg er avdelingslege i Hærens sanitet. Spesialist i fysikalsk medisin og rehabilitering, og Ph.d.

Ingen oppgitte interessekonflikter.

Jeg leste med interesse Tor-Erik Widerøes innlegg om mettet fett og epigenetikk (1).

Som leger i Forsvaret selekterer vi ut soldater til oppdrag i utlandet med risiko for potensiell posttraumatiske komplikasjoner. Hvis det er slik at epigenetiske forandringer kan arves videre til barn og muligens også til flere generasjoner, blir jeg urolig. Gitt at en militær traumatisk eksponering gir epigenetiske forandringer, kan det tenkes at «uskyldige» ofre som barn av vedkommende soldat påføres epigenetiske forandringer som igjen kommer til uttrykk i dårligere helse (2). Har jeg som militærlege rett til å påføre «uskyldige» etterkommere av en soldat en dårligere helse?

\section{LITTERATUR:}

1. Widerøe T-E. Kosthold, mettet fett og epigenetikk. Tidsskr Nor Legeforen 2018; 138: 222. [PubMed]

2. Brubaker CR, Milner J. The epigenetics of post-traumatic stress disorder in women and PTSD in women veterans: implications for health policy. DNP Forum 2015; 1, nr. 1, art 7.

Publisert: 5. mars 2018. Tidsskr Nor Legeforen. DOI: 10.4045/tidsskr.18.0147

(C) Tidsskrift for Den norske legeforening 2020. Lastet ned fra tidsskriftet.no 